\title{
Food Issue and Need for its Normative and Legal Regulation in Russia
}

\author{
${ }^{1}$ T.M. Yarkova, ${ }^{2}$ O.I. Khairullina \\ ${ }^{1}$ Doctor of Economics, Professor of Organization of Agricultural Production Department of the Federal State \\ Budgetary Educational Institution of Higher Education «Perm State Agro-Technological University named after \\ Academician D.N. Pryanishnikov» Perm, Russia \\ ${ }^{2}$ Doctor of Economics, Professor of Accounting and Finance Department of the Federal State Budgetary \\ Educational Institution of Higher Education «Perm State Agro-Technological University named after Academician \\ D.N. Pryanishnikov» Perm, Russia \\ Email: tanyayarkova@ya.ru,o.i.khayrullina@mail.ru
}

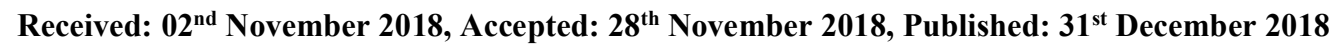

\begin{abstract}
A special attention should be paid to the issues of food security and its normative and legal regulation at the present stage of society development. The article determined the main stages of food security issue development and study in Russia and abroad. They determined the critical periods of the post-Soviet space, characterized by the catastrophic state of food dependence and the decline of the economy agrarian sectors. They performed the analysis of the current normative and legal regulation in Russia and abroad. They attempted to assess the degree of food security issue legal regulation in Russian Federation due to the absence of the federal law which allows to control and ensure food and national security. They gave the recommendations for normative and legal regulation improvement.
\end{abstract}

Keywords

Food Security, Food Independence, Normative and Legal Regulation, Agriculture, Russia, Food Crisis

\section{Introduction}

Food security is the most important task of national security provision for any state.

However, it was not a priority for Russia, in spite of the long period of this problem research. Especially this fact was evident in the post-Soviet space. This period of time turned out to be the most destructive for the food security of the country, since agriculture and the agro-industrial complex were destroyed under the influence of market economy laws.

Of course, the laws of market economy are completely subject to effective functioning, but Russia at that time could not afford to exercise a proper state support to the agricultural sector in the form of transfers and subsidies from the federal and regional budgets due to the extremely deficit budget and huge external debts [1]. At the same time, it is known that the agricultural potential of the country ensures its food security.

For modern Russia, the problem of food security became apparent only during the last two decades of the 20th century, although the concept of food security as the problem at international sites entered into an active discussion a little bit earlier (in 1972-1973). The cause of this phenomenon was the global and serious grain crisis [2]. During that period many world powers began to solve food problem actively both within the country and at the external market. As an example, one can cite the experience of some state developments. So they issued the law "On agriculture security of Germany" in 1955, where the main state strategic priority was the population supply with food. In 1985, the "US Food Security Act" began to work in the United States, which allowed the building of highly efficient state support to farmers to secure the domestic food market completely.

In Russia, the introduced primary regulatory act is the "Food Security Doctrine" (2010), which gives the generally accepted definition of food security, which states that this is the country economy state that ensures food security of Russian Federation, physical and economic accessibility of food products is ensured for every citizen of the country that meet the requirements of Russian Federation legislation on technical regulation, in the amounts not less than the rational norms of food consumption necessary for an active and a healthy lifestyle [3, 4].

It is important to note that in this article the author focuses on the typology of regulatory documents that allow to regulate, coordinate and control the issues of state food security. In this regard, it is important to note that Russian Federation still does not have the Federal Law "On Russian Federation Food Security". This only proves the problematic nature of the agricultural food problem and its regulatory framework. This judgment is entirely conditioned by a number of factors, which will be discussed in this scientific article.

\section{Research methodology and methods}

In order to conduct a scientific study on the problem of normative regulatory regulation of food safety issues, the well-known methods were used as the basis, such as the retrospective, factual analysis, as well as the method of expert assessments.

The studies were conducted on the basis of existing scientific developments of scientists, economists, researchers and current regulatory legal acts on the territory of Russia. They also took into account the international experience of the regulatory framework for food security. 
Research results. The retrospective analysis revealed that in Russia and the whole world, the problem of population provision with food was solved by stockpiling initially, and only in the second half of the 20th century did the Soviet and the world community began to study and solve the problem of food security.

Based on the long-term results of our own research, it should be noted that the conducted retrospective analysis made it possible to determine the initial stage of food security problem solution, which originated in the XVII-XVIII centuries (tab. 1).

\begin{tabular}{|c|c|}
\hline Period & Main Goals and Objectives in the Field of Food Issue \\
\hline $\begin{array}{l}\text { XVII-XVIII } \\
\text { cent. }\end{array}$ & $\begin{array}{l}\text { The times of Peter I: the creation of efficient transport interchanges to create food supplies for military needs. } \\
\text { The times of Paul I: Grain reserve provision for civilians [5] }\end{array}$ \\
\hline $\begin{array}{l}20 \text {-ies of the } \\
\text { XXth century }\end{array}$ & $\begin{array}{l}\text { The creation of state grain reserves using the first developed methodology for food consumption } \\
\text { calculation per capita in a year. Food provision rate (calculation of grain) made about } 50 \% \text { [6] }\end{array}$ \\
\hline $\begin{array}{l}50 \text {-ies of the } \\
\text { XXth }\end{array}$ & $\begin{array}{l}\text { The Central Committee of RSFSR CPSU approved the measures for agricultural production } \\
\text { intensification. Purpose: "nationwide" struggle for a steep rise of agriculture. The grain provision } \\
\text { rate in the country did not exceed } 40 \% \text { [7] }\end{array}$ \\
\hline $\begin{array}{l}\text { 70-ies of the } \\
\text { XXth }\end{array}$ & $\begin{array}{l}\text { Planned economy of the USSR. Sustainable agricultural policy. Regulatory stocks and consumption. } \\
\text { The security is high. The dependence on imports makes about } 10 \% \text {. }\end{array}$ \\
\hline $\begin{array}{l}\text { 80-ies of the } \\
\text { XXth }\end{array}$ & $\begin{array}{l}\text { The negative effects of political adjustment on market relations. The increase of food shortages. } \\
\text { Import dependence grows and reaches } 20 \% \text {. }\end{array}$ \\
\hline $\begin{array}{l}\text { 90-ies of the } \\
\text { XXth }\end{array}$ & $\begin{array}{l}\text { The reduction of state support to farmers in } 10 \text { times due to the budget deficit. The issue of food } \\
\text { security is acute in scientific circles. The work has begun on the preparation of a number of legal } \\
\text { acts in the field of food security. The develop state program drafts for the development of agriculture } \\
\text { and food security in a five-year period [8]. }\end{array}$ \\
\hline $2000-2009$ & $\begin{array}{l}\text { The lack of or a weak attention to food issues in the adopted legal acts. } \\
\text { The Doctrine of RF Food Security (2010) is adopted and approved by RF Decree. RF Ministry of } \\
\text { Health and Social Development developed the rational norms for the consumption of basic } \\
\text { foodstuffs different from those recommended by the WHO of UN and Food Research Institute of the } \\
\text { Russian Academy of Medical Sciences }[7,8] \text {. The level of food dependence is more than } 35 \% \text {. }\end{array}$ \\
\hline $2010-2013$ & $\begin{array}{l}2012 \text { - Russia joined the WTO, the program of federal importance was developed for the } \\
\text { development of agriculture and the regulation of agricultural product, raw material and food } \\
\text { markets for the period of } 2013-2020 \text {. }\end{array}$ \\
\hline $\begin{array}{l}\text { Since } 2014 \\
\text { until now }\end{array}$ & $\begin{array}{l}\text { The course has been taken on import substitution in connection with the sanctions pressure of the } \\
\text { United States and the European Union countries. The food import was reduced. }\end{array}$ \\
\hline
\end{tabular}

Table 1: Retrospective Analysis of Russian State Food Security Issue Study*

Based on the data in Table 1, it should be emphasized that there was no sensation of an obvious food problem in the USSR during the 70-ies of the last century. However, this period should be singled out in connection with the fact that an important resolution was adopted on the transnational responsibility for food security provision in the world at the international level, at the regular meeting of the UN General Assembly [8]. Also in the framework of food security issue international study, the Rome Declaration on World Food Security was adopted during the same period.

So, during the times when the USSR was in conditions of planned economy, it was possible to observe practically the most efficient system of agriculture in the world. During the times of the "union" development, agriculture increased the gross output more than 4 times. During the same period, the country shifted quickly from manual labor, having increased the productivity 36 times. It should be noted also the fact that the USSR occupied the leading place in terms of production growth, not giving a chance to be ahead either to the United States, Germany or France.

Today we can ascertain the facts testifying to the catastrophe in agriculture, which are terrifying. Here are some of them. For example, since 1992 the number of cattle has decreased by 2.8 times and amounted to 18.7 million heads by 2017 , including cows - by 2.5 times; pigs - 1.4 times, sheep and goats - 2 times. The agricultural equipment not only worn out, but also reduced. This can be proved by the statistical information that the number of tractors has decreased by 6 times; combine harvesters - 7 times, etc. [9]. Most of Russians remember the results of the first years of "perestroika". These are social upheavals, food shortages, food rationing system. All this testifies to the current food disaster and the low level of food security in the country. Of course, not all agricultural performance indicators are negative. However, this does not reduce the acute nature of the developed problem.

Here we should pay a close attention to the fact that the issues of food security in Russia at the state level were taken into account only during deep economic and agri-food crisis. 
In 1996-1998 scientists and politicians have developed such legal documents as the Food Security Doctrine and the Federal Law on Food Security. However, during that period of time no legislative act was signed by the president. Let's consider some of the facts of this event.

Based on the official documents provided by the reference and legal systems, it should be noted that in 1996, the deputies of RF State Duma P.T. Burdukov and V.I. Ilyukhin submitted the federal law draft on RF food security. This law defined the basic concepts of key terms: RF food security, food security provision, emergency food situation, physiological nutritional standards, vital food products, RF food independence, the necessary level of food production, the physical accessibility of food, economic affordability of food and state food reserve. The main articles of this draft federal law were focused on the program effective development of the agrarian sectors, the establishment and the maintenance of food supply processes for the population and the saturation of the domestic food market. The same document focuses on the predominance of international regulatory act status, and also determines the degree of responsibility for food security provision by state and regional authorities. Such a promising and strategically successful document, which passed all revisions and readings, was adopted in RF State Duma on December 10, 1997.

However, a year later, the RF President of the Russian Federation B.N. Yeltsin pointed out the illegality of some positions in the draft Federal Law "On Food Security" in his letter of opinion (April 13, 1999) No. Pr-480, and, accordingly, withdrew it from consideration. The President noted contradictory constitutional legislative acts of the Articles 6 and 8 as the reasons, which defined the powers and control functions of the executive authorities of Russian Federation subjects. At that the President pointed out the following: this excludes the powers of RF President and the Government. The final paragraph of this document has the phrase defining the fate of the Federal Law draft "On RF Food Security": "Besides, the bill is declarative and does not have its own regulation subject" [10].

No one knows whether this is the reason for the removal of such an important document from consideration. The scientific community does not have any other facts. But the inconsistency of this situation is fully justified and objective. At the same time period of 1998, the Food Security Doctrine was not signed. It should be noted that these documents complement each other and, to be more precise, the federal law comes first in terms of importance, requiring mandatory implementation, and the Doctrine is only the basis for its development, a kind of target with a set of important tasks, functions and evaluation indicators.

In 2008, the world, including Russia, was gripped by an economic crisis, which affected the agro-industrial sector even more deeply and aggravated food dependence. A wave of negativity from the scientific and political community of Russia has gone beyond its limits. It was activated not only by the crisis, but also by the upcoming events on Russia accession to the WTO. The President and the Government could not remain indifferent to the legal regulation of food security issues. And, naturally, they developed and President D. Medvedev signed the Doctrine of RF Food Security. Along with it, the norms of consumption of basic types of food were developed by the Ministry of Health and Social Development, however, there was no federal law.

Speaking of the Doctrine and its perfection, as a regulatory act, one can say a lot, but the author would like to note two important points that should be paid attention to. Thus, the Food Security Doctrine proposes two generally accepted definitions of the concepts: "food security" and "food independence". At the same time, food independence is an integral part or, in another way, a security element of food security. Although it is customary to distinguish these two concepts from the following positions in scientific circles: independence should be focused on its own domestic production, and safety on quality, physical and economic availability of food at any time for the country population, which in the latter case cannot completely exclude import for Russia. And the second point: the Doctrine, taking into account many risk factors of the internal and external environment, should be developed for a certain period of time, since it has targets and corresponding evaluation criteria, which can and should be adjusted in time. So, now the issue of the "new" Doctrine has been discussed and even its project exists, which does not take the form of an existing legal act for quite a long time, i.e. for 4 years.

At the same time, it should be noted that the Laws "On Food Security" exist on the territory of Russia, but they have been developed and put into effect by RF subjects. As an example, one can cite large single-industry towns (St. Petersburg, Moscow) and some regions: Kostroma Region, Ulyanovsk Region, Kursk Region, Primorsky Krai, the Republic of Bashkortostan. It is important to emphasize that not all of these regions are related to the strategy of food security and state and regional independence provision. Meanwhile, all of the indicated regions of Russia developed their own Laws, focused only on the regional level in completely different periods of time, from 2000 to 2009. With the adoption of the Doctrine, they were amended accordingly, with the exception of the Law of the Republic of Bashkortostan.

Based on a number of existing studies on this issue, it is also possible to highlight the fact that all regional laws are not unified, i.e. the list of articles and their essence differ significantly among themselves [11]. In these Laws, the indicators of food security assessment set forth in the Doctrine do not appear almost, which is not acceptable for their performance at the proper level. 
Conclusion

Based on the above stated research results, it is important to note that it is impossible to consider the legal regulation of food security issues only at the national level. In this regard, the following vision of the regulatory framework is proposed at the international and national levels (Fig. 1).

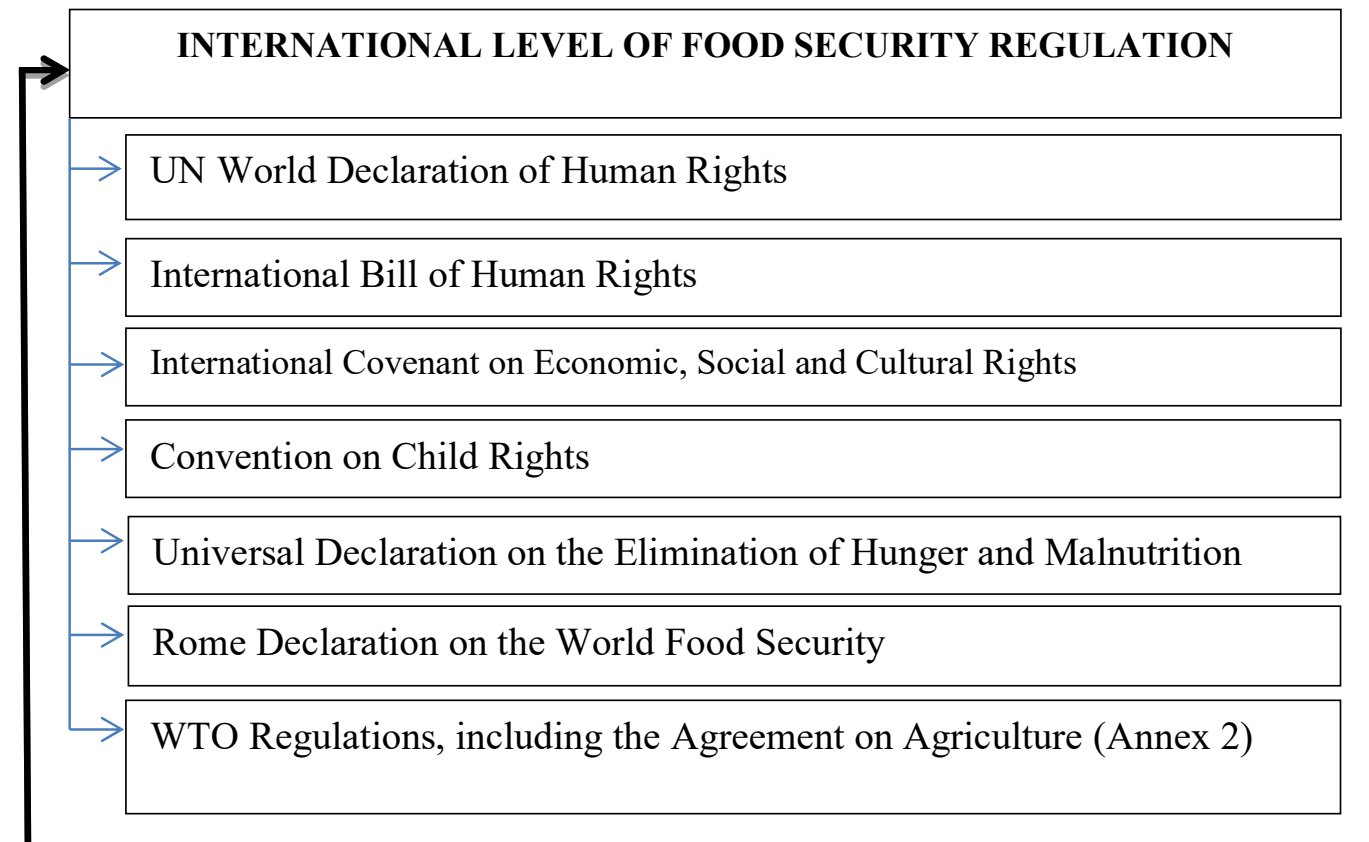

\begin{tabular}{|l|}
\hline NATIONAL LEVEL OF FOOD SECURITY REGULATION \\
\hline$\rightarrow$ Food Security Doctrine \\
\hline
\end{tabular}

\begin{tabular}{l}
$\rightarrow$ Federal Law "On RF Food Security" \\
\hline Regional Laws On Food Security \\
\hline
\end{tabular}

$\rightarrow$ Federal Law "On the Development of Agriculture"

State Program for the Development of Agriculture and the Regulation of Agricultural Product, Raw Material and Food Markets

$$
\text { V }
$$

Regional Programs for the Development of Agriculture .....

$\rightarrow$ Development strategy for RF food and processing industry

$\rightarrow$ Federal Law "On Oualitv and Food Safetv"

Federal Law "On the supply of products for federal state needs"

Figure 1: Interrelation of Normative and Regulatory Regulation Elements Concerning the Problem of Food Security in Russia (Compiled by the Author Using Data Sources [12, 13, 14] 
Thus, it can be argued that Russian Federation currently needs a basic document - the Federal Law "On Food Security", which allows to solve many strategic tasks set by the state. Regional Laws may be formed only on the basis of the Doctrine and Federal Law. At the same time, the structure of regional Laws with the basic provisions should be unified, while the requirements or targets should be differentiated depending on their territorial branch affiliation and the availability of agrarian and industrial potential.

Such an approach will allow to form an effectively interacting system of food security provision at the state level, and will not contradict the main regulatory and legal acts of the international level.

\section{References}

1. Bagavudinova M.B. Regional problems of economic transformation. - 2016. - №4. - pp. 25-28

2. Miloserdov K.V. Food Security in the World // Agri-Food Policy. - 2013. - №11 (23). - pp. 7-12

3. Presidential Decree (January 30, 2010) No. 120 "On RF Food Security Approval” [Electronic resource] / SPS GARANT. - Access mode: http://base.garant.ru/12172719/\#ixzz5UPTL15fE

4. Piskov G.M. The condition of the food market in Russia and its role in food security provision of the country // Bulletin of VolSU. Series 3: Economy. Ecology. 2009. №1. - pp. 105-110.

5. Nazarenko V.I. Stocks and food consumption in Russia. Historical essay [Text] / V.I. Nazarenko // Economics of agricultural and processing enterprises. - 2011. №7. - pp. 7-11.

6. Kuzin V.N. Food Security as a Scientific Category and a Practical Problem [Text] / V.N. Kuzin // Bulletin of the Volga Region Academy of Public Service. - 2010. №1. - pp. 163-170

7. Shevelkov A.I. Agrarian policy and food supply problem solution among RSFSR population during the second half of the XX century [Text] / A.I. Shevelkov // Agrarian Bulletin of the Urals. - 2010. №9 (75). - pp. 37-41

8. Savitskaya, E.A. Food security: historical, economic and social aspects [Text] / E.A. Savitskaya // Agrarian Bulletin of the Urals. - 2010. №3 (69). - pp. 37-39

9. Russia in numbers. 2018: Summary of Statistics / Rosstat - M., 2018 - 522 p.

10. The letter of RF President (dated on April 13, 1999) No. Pr-480 "The conclusion on the draft of the Federal Law "On RF Food Security" [Electronic resource] / SPS ConsultantPlus. - Access mode: http://www.consultant.ru/cons/cgi/online.cgi?req=doc\&base=PRJ\&n=33850\#003423614107327677

11. Kovaleva I.V., Vodyasov P.V. The doctrine of RF food security as the basis for the development of guidelines in the field of regional food security // Bulletin of the Altai State Agrarian University. - 2015. - №9 (131). - pp. 145150 .

12. Capone R., El Bilali H., Debs P. et al. Food System Sustainability and Food Security: Connecting the Dots // Journal of Food Security. 2014. Vol. 2. - № 1. - pp. 13-22.

13. CFS, Coming to terms with terminology: Food security, Nutrition security, Food security and nutrition, Food and nutrition security // Committee on World Food Security (CFS), Thirty-ninth Session, Rome, 15-20 October 2012. Global Food Security, Strategic Plan 2011-2016. URL: http://foodsecurity.ac.uk/assets/pdfs/gfs-strategic-plan.pdf. 14. Olaoy O.A. Potentials of the Agro Industry towards Achieving Food Security in Nigeria and Other Sub-Saharan African Countries // Journal of Food Security. - 2014. - Vol. 2. - № 1. - pp. 33-41. 